\title{
Review
}

\section{Seeing like an activist: Civil disobedience and the civil rights movement}

\author{
Erin R.Pineda, Oxford: Oxford University Press, 2021, 265pp., \\ ISBN 978-0197526439
}

Contemporary Political Theory (2023) 22, S38-S41. https://doi.org/10.1057/s41296021-00545-2; published online 11 January 2022

Seeing Like an Activist provides an original critique of the prevailing interpretation of civil disobedience going back to the American civil rights era. More precisely, Erin Pineda presents a revisionist and recontextualizing reading of the political thought of the activists who drove this movement that rejects the standard account of civil disobedience in liberal political theory. Seeing Like an Activist further offers a refreshing way of practicing political theory, even if this methodological contribution remains mostly implicit. This review begins with a brief reconstruction of the argumentative structure of the book. I then discuss its most important contributions, paying particular attention to explicating its potential for informing methodological debates.

The book is motivated by the recurring invocations of acts of civil disobedience during the short civil rights movement of the 1950s and 1960s, not only by contemporary politicians and state officials, but also by liberal political theorists. Pineda claims that these appeals misinterpret these historical cases of civil disobedience, stripping the responsible activists of their agency as political thinkers and reducing their intellectual contributions by making them mere reactions to an "almost" just liberal order. By portraying civil disobedience as the standard for acceptable forms of protest, they further tend to delegitimize other forms of protest.

The first chapter shows that liberal political theories of civil disobedience, as exhibited primarily by John Rawls and his followers, Michael Walzer, and Hugo Bedau, occlude our ability to assess the original political theorizing at the heart of the civil rights movement because they encourage us to 'see like a white state' (40-49). More concretely, their focus on justifications for breaking the law, misinterpretation of civil disobedience campaigns as communicative acts aimed at the morality of the majority, and emphasis on the affirmation of the constitutional order through the ready acceptance of punishment, constitute the perspective of a state, which can recognize the racially oppressive elements of its order only in bad faith applications, but not in its foundation. These theories thus limit civil disobedience to its system-justifying elements.

(C) 2022 The Author(s), under exclusive licence to Springer Nature Limited. 1470-8914 Contemporary Political Theory Vol. 22, S1, S38-S41

www.palgrave.com/journals 
The rest of the book draws on a mixture of archival source analysis and the reconstruction of public discourse during the civil rights era to unearth the political thought of civilly disobedient activists. This exercise has the twinned goals of building an alternative to the liberal interpretation of civil disobedience and loosening the latter's grip on us.

The second chapter recontextualizes the emergence of civil disobedience as a tool of American civil rights activists against the background of longstanding global movements for decolonization and liberation from racialized oppression. It reconstructs the debates for and against non-violent direct action, with special focus on the direct links of Mohandas Gandhi and Kwame Nkrumah with African American activists. The third and fourth chapters illuminate the political and ethical vision of the activists and demonstrate how their motivations differed in crucial ways from the liberal interpretation.

Chapter 3 compellingly shows that the jail-ins of activists in the South had less to do with readily accepting punishment and more to do with gaining freedom by overcoming the fear connected to the Southern jail by turning it into space for liberatory struggle. Chapter 4 reviews Martin Luther King Jr.'s 1964 Birmingham campaign, demonstrating that its main goals were the disruption of the order of white supremacy and the disclosure of the brutality beneath its veneer of civility. Pineda concludes that achieving these goals depended on a violent response, both by the authorities and by African American bystanders, which complicates the understanding of civil disobedience as centered on non-violence.

The fifth chapter uses the failed stall-in campaign aimed at the New York World's Fair in 1964 to analyze how the response of Northern moderate and liberal whites to civil disobedience contributed to the white vision of the US state. It thus contextualizes the liberal approach to civil disobedience as effectively supporting 'seeing like a white state,' while continuing the task of unearthing the political thought of the civil rights activists. The epilog reflects on how the findings of these case studies can inform our interpretation of contemporary protests and struggles of Black Americans.

Seeing Like an Activist makes three distinct points, even if the book is not as clear as it could be about the range of its contributions and interventions. The first is critical. Pineda shows that liberal theories of civil disobedience not only fail to interpret what motivated civilly disobedient activists during the civil rights movement, but they are also structured to conserve the status quo, e.g., by limiting the forms of acceptable protest.

The second contribution is her revisionist reading of the meaning of civil disobedience in the US civil rights movement. This contribution, not least to intellectual and social history, has two dimensions. First, several case studies show how treating activists as political thinkers in their own right provides the basis for replacing the framing of civil disobedience by liberal theories. Instead of focusing on justifying an almost just order through fidelity to the law during the act of

(C) 2022 The Author(s), under exclusive licence to Springer Nature Limited. 1470-8914 Contemporary S39 Political Theory Vol. 22, S1, S38-S41 
breaking it, this interpretation focuses on decolonizing struggles. Second, Pineda complicates the understanding of a core component of civil disobedience-the commitment to refraining from violence-by looking at the ethical and political motivations of activist groups, the strategic considerations of leaders, and the interaction between the civil rights movement and the wider American public. In short, her account enables a more comprehensively political account of civil disobedience in the US civil rights movement.

The third contribution is methodological. The shift Pineda seems to proposealready in the book's title-presumably gains its importance from its potential for changing how political theory is practiced. If we take the structure of the book as exemplary of this shift, we see contextual political theorizing from the bottom up, closely intertwined with social and intellectual history. We also see an inquiry into the history of the present uses of civil disobedience in public discourse, which has the effect of changing the question. Instead of asking 'what counts as civil disobedience?' the question that emerges is, 'what are the politics of civil disobedience in this context?' This approach, which is relatable to genealogy, repoliticizes civil disobedience.

The book's contribution to methodological debates in political theory can be most clearly discerned if one views it as aiming for interdisciplinary diagnosis and evaluation-at the same time as engaging in a revisionist social and intellectual history, and in a (conceptual) genealogy to furnish us with better tools for understanding and assessing political claims offered by activists to a wider audience. Engagement with recent methodological literatures, e.g., recent radical realist projects in political theory and their connection to critical theory (Cross, 2021; Prinz \& Rossi, 2017), could have helped bolster this contribution.

While the book's first two contributions are successfully substantiated, neither the third one nor the connections between the three levels are clearly articulated. This is unfortunate, as the notion of 'seeing like an activist' could possibly have connected all three levels. Not only does it raise questions about the 'vision' of liberal theories of disobedience, learning to 'see like an activist' would also enable political theorists to access and interpret materials that can challenge and revise these theories. Finally, these materials could be gathered into a set of commitments for doing political theory differently.

Unfortunately, Pineda does not make clear what exactly 'seeing like an activist' means for the second and third levels. This problem is partly due to the lack of dialog with social movement theory and social epistemology to address questions about the promises and limitations of activist perspectives. This line of criticism does not, however, fundamentally undermine the value of book, which is worth reading for the moving interpretations of civilly disobedient activists. It does mean 
that it presents only an inspiration rather than a preliminary theorization of what it would mean to practice political theory while 'seeing like an activist.'

\section{Note}

1. There is a missed opportunity here for engagement with Katrina Forrester's recent discussion of the intellectual context of liberal theorists of civil disobedience in "In the Shadow of Justice" (Forrester, 2019), if only because it could have provided the same level of contextual embedding to liberal theorists of civil disobedience that is provided for civil rights activists.

\section{References}

Cross, B. (2021) How radical is radical realism? European Journal of Philosophy. https://doi.org/10. 1111/ejop. 12710 .

Forrester, K. (2019) In the Shadow of Justice. Postwar Liberalism and the Remaking of Political Philosophy. Princeton University Press.

Prinz, J. and Rossi, E. (2017) Political realism as ideology critique. Critical Review of International Social and Political Philosophy 20(3): 348-365. https://doi.org/10.1080/13698230.2017.1293908.

Publisher's Note Springer Nature remains neutral with regard to jurisdictional claims in published maps and institutional affiliations.

Janosch Prinz

Maastricht University, Maastricht $6200 \mathrm{MD}$, The Netherlands j.prinz@maastrichtuniversity.nl 